\title{
Intracranial variables in propofol or sevoflurane-anesthestized dogs subjected to subarachnoid administration of iohexol
}

\author{
[Variáveis intracranianas em cães anestesiados com propofol ou sevofluorano e submetidos \\ à administração subaracnóidea de iohexol] \\ N. Nunes ${ }^{1}$, A.V. Leite ${ }^{2}$, D.P. Paula ${ }^{2}$, C.T.D. Nishimori ${ }^{3}$, A.P. Souza ${ }^{4}$, P.S.P. Santos ${ }^{5}$, \\ P.N. Henao Guerrero ${ }^{6}$, P.C.F. Lopes ${ }^{7}$ \\ ${ }^{1}$ Faculdade de Ciências Agrárias e Veterinárias - FCAV-UNESP - Campus de Jaboticabal \\ Via de Acesso Prof. Paulo Donato Castellane s/n \\ 14884-900 - Jaboticabal, SP \\ ${ }^{2}$ Médica veterinária autônoma \\ ${ }^{3}$ UNIFRAN -Franca, SP \\ ${ }^{4}$ Unidade Acadêmica de Medicina Veterinária - Universidade Federal de Campina Grande - Patos, PB \\ ${ }^{5}$ Faculdade de Medicina Veterinária de Araçatuba - FMVA - UNESP - Araçatuba, SP \\ ${ }^{6}$ Department Small Animal Clinical Sciences, Virginia-Maryland Regional College of Veterinary Medicine at \\ Virginia Tech, Blacksburg, VA, USA \\ ${ }^{7}$ Aluna de pós-graduação - FCAV-UNESP - Jaboticabal, SP
}

\begin{abstract}
The effects of subarachnoid administration of iohexol on intracranial hemodynamic in dogs anesthetized with propofol or sevoflurane were evaluated. Thirty adult animals $(10.9 \pm 2.9 \mathrm{~kg})$ were distributed into two groups: PG, where propofol was used for induction $(10 \pm 0.5 \mathrm{mg} / \mathrm{kg})$, followed by a continuous rate infusion at $0.55 \pm 0.15 \mathrm{mg} / \mathrm{kg} /$ hour, and SG, where sevoflurane was administered for induction (2.5 MAC) and for anesthetic maintenance (1.5 MAC). A fiberoptic catheter was implanted on the right superficial cerebral cortex to monitor intracranial pressure (ICP). After 30 minutes, cerebrospinal fluid (CSF) was collected at the cisterna magna and iohexol was injected. The measurements were performed before CSF collection (TA), after the iohexol injection (T0), and at 10-minute intervals (T10 to T60). Intracranial pressure decreased at T0 in SG. Cerebral perfusion pressure at T0 was higher than at TA, T50 and T60 in PG, but in SG, the mean value at T0 was higher than the ones from T20 to T60. Mean arterial pressure at T0 was higher than at TA in PG, while in SG, the values from T20 to T60 were lower than at T0. The heart rate at T60 was lower than at T0 in PG. Cardiac output at TA was lower than at T60 in SG. The cerebrospinal fluid collection and administration of iohexol promoted decrease in intracranial pressure in sevolflurane-anesthetized dogs and increase in cerebral perfusion pressure in propofol-anesthetized dogs.
\end{abstract}

Keywords: anesthesia, dogs, cerebral autoregulation, myelography

\section{RESUMO}

Avaliaram-se os efeitos da administração subaracnóidea de iohexol sobre a hemodinâmica intracraniana em cães anestesiados com propofol ou sevofluorano. Trinta e dois animais $(10,9 \pm 2,9 \mathrm{~kg})$ foram distribuídos em dois grupos: no GP, o propofol foi usado para indução, $10 \pm 0.5 \mathrm{mg} / \mathrm{kg}$, seguido por

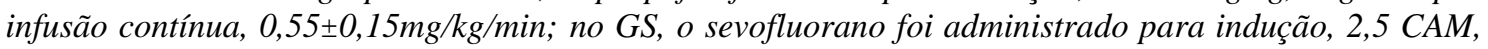
e manutenção, 1,5 CAM, da anestesia. O cateter de fibra óptica foi implantado na superfície direita do córtex cerebral para monitorar a pressão intracraniana (PIC). Após 30 minutos, o fluido cerebroespinhal (FCS) foi coletado da cisterna magna e o iohexol injetado. As mensurações ocorreram antes da coleta do FCS (TA), depois da injeção de iohexol (T0) e em intervalos de 10 minutos (T10 a T60). A pressão intracraniana diminuiu em T0 no GS. A pressão de perfusão cerebral em T0 foi maior que em TA, T50 e T60 no GP, mas no GS, a média em T0 foi maior que as de T20 a T60. A pressão arterial média em T0 foi

Recebido em 12 de julho de 2010

Aceito em 18 de julho de 2011

E-mail: newton@fcav.unesp.br 
maior que em TA no GP, enquanto no GS, de T20 a T60, as médias foram menores que em T0. A frequência cardíaca em T60 foi menor que em T0 no GP. O débito cardíaco em TA foi menor que em T60 no GS. A coleta do fluido cerebroespinhal e a administração do iohexol promoveram a diminuição da pressão intracranina em cães anestesiados com sevofluorano e aumento da pressão de perfusão cerebral em cães anestesiados com propofol.

\section{Palavras-chave: cão, anestesia, autoregulação cerebral, mielografia}

\section{INTRODUCTION}

In veterinary medicine, myelography is a widely employed procedure for the diagnosis of spinal lesions and can be carried out with standard inexpensive radiographic techniques. In order to perform this technique, general anesthesia, constant monitoring and adequate ventilatory support are necessary (Leite et al., 2002).

Propofol is an intravenous hypnotic agent with short action duration (Quandt et al., 1998), and can be used for anesthetic induction and/or maintenance, administered as an intermittent bolus or continuous infusion (Deneuche and Debois, 1999). At doses ranging from 5 to $10 \mathrm{mg} / \mathrm{kg}$, propofol promotes rapid, smooth induction, without signs of excitement (Glowaski and Wetmore, 1999). In premedicated, debilitated or elderly animals, the dose can be reduced from 20 to $80 \%$ (Short and Bufalari, 1999). Ferro et al. (2005) used, in dogs, continuous infusions ranging from 0.2 to $0.8 \mathrm{mg} / \mathrm{kg} /$ minute.

The use of propofol for anesthesia induction or maintenance is associated with a discreet reduction in arterial blood pressure (Short and Bufalari, 1999), which is proportional to the increase of drug plasma concentration (Whitwam et al., 2000). Propofol does not seem to impair cerebral autoregulation (Omoigui, 1998; Paula $e t$ al., 2010), even though it can reduce cerebral blood flow (CBF) (Omoigui, 1998), cerebral oxygen consumption (Ravussin et al., 1988) and intracranial pressure (ICP) (Bazin, 1997; Paula et al., 2010). The ICP reduction is associated with an increase in cerebral vascular resistance, which allows the maintenance of perfusion pressure (Magella and Cheibub, 1990).

Sevoflurane is a fluorinated isopropylic ether with minimum alveolar concentration (MAC) of $2.36 \%$, in dogs (Clarke, 1999). It's low bloodgas solubility coefficient $(0.68)$ provides rapid anesthetic induction and recovery, with minimal irritation of the upper airways, low incidence of coughing and laryngospasm, fast control of anesthetic depth and preservation of the spontaneous ventilation (Charles and Fallon, 2000). This inhalant anesthetic has a dosedependent negative inotropic effect (Hanouz et al., 2000), increasing coronary blood flow and decreasing myocardial oxygen consumption (Crystal et al., 2000), but it decreases arterial blood pressure and systemic vascular resistance (Branson et al., 2001).

The effects of this agent on cerebral hemodynamics are controversial. Monkhoff et al. (2001) described a CBF increasing with a consequent increase in ICP, due to vasodilatation, variations in systemic arterial blood pressure and the loss of the cerebral vascular autoregulation. According to Omoigui (1998), the CBF increase is attenuated with time and reflects the restoration of cerebral vascular autoregulation. Schwender et al. (1998) believed that during sevoflurane anesthesia, cerebral vascular autoregulation and the $\mathrm{CBF}$ response to changes in $\mathrm{CO}_{2}$ partial pressure are usually preserved.

Iohexol is a non-ionic, water soluble, contrast agent, used for myelography in dogs (Leite et al., 2002). The most used iohexol concentrations range from 180 to $350 \mathrm{mg} / \mathrm{mL}$ (Simon and Nicholas, 1999). Lewis and Hosgood (1992) indicate an iohexol concentration of $240 \mathrm{mg} / \mathrm{mL}$ and doses from 0.3 to $0.5 \mathrm{~mL} / \mathrm{kg}$. Comparatively, iohexol and the other contrast agent, iopamidol, do not differ between each other regarding the quality of the images produced or the adverse reactions (Widmer et al., 1992). Lewis and Hosgood (1992) observed a lower incidence of seizure after iohexol use when compared to the contrast agent, metrizamide.

Considering the risks associated with the radiographic technique of myelography and the paucity of information regarding the cerebral hemodynamic changes, this study was carried 
out to evaluate the possible alterations in intracranial hemodynamics of dogs submitted to subarachnoid administration of iohexol, anesthetized with propofol or sevoflurane.

\section{MATERIAL AND METHODS}

Thirty adult mongrel dogs, mean age $4 \pm 1.5$ years old, weighing $10.9 \pm 2.9 \mathrm{~kg}$, were enrolled in the study. The animals' health was attested by a physical examination and complete blood count, blood chemistry profile and serologic tests for toxoplasmosis and leptospirosis. The dog's body condition was maintained ideal (score 3). Food was withheld for 12 hours and water for 2 hours before the beginning of the anesthesia. The dogs were randomly distributed in two groups of 15 animals each.

For the propofol group (PG), animals were induced to anesthesia by intravenous administration of propofol (Diprivan, Zeneca Farmacêutica do Brasil Ltda., São Paulo, SP, Brazil), at the dose of $10.0 \pm 0.5 \mathrm{mg} / \mathrm{kg}$. After endotracheal intubation, the dogs received $100 \%$ oxygen at $30 \mathrm{~mL} / \mathrm{kg} /$ minute flow, through an anesthetic circuit with partial rebreathing of gases (Mod. Excel 210SE, Datex Ohmeda, Madison, WI, USA (Proc. FAPESP 97/10668 4)). Anesthesia was maintained with propofol administered continuously by an infusion pump (Fars 600, Lifemed Pesquisas Médicas Ind. e Com. Ltda., São Paulo, SP, Brazil), at a rate of $0.55 \pm 0.15 \mathrm{mg} / \mathrm{kg} / \mathrm{minute}$. The continuous rate infusion of this drug was adjusted to maintain each animal in stage III, plane $2 / 3$ according to Guedel planes.

In the sevoflurane group (SG), animals were induced with sevoflurane (Sevorane, Abbott Laboratórios do Brasil Ltda, São Paulo, SP, Brazil) at 2.5 MAC, measured with a gas analyzer (Mod. 5250 RGM, Datex Ohmeda, Madison, WI, USA). The inhalant anesthetic was administered through a calibrated vaporizer (Mod. Sevotec 5, Datex Ohmeda, Madison, WI, USA), diluted in a $150 \mathrm{~mL} / \mathrm{kg} /$ minute oxygen flow, using a sealed mask and an anesthetic circuit with partial rebreathing of gases, during the time required to allow endotracheal intubation. After intubation, oxygen flow was adjusted to $30 \mathrm{~mL} / \mathrm{kg} / \mathrm{minute}$ and the vaporizer turned down until end-tidal sevoflurane concentration was maintained at 1.5 MAC, measured with a gas analyzer, to maintain the animals in stage III, plane $2 / 3$ according to Guedel planes.

The dogs were positioned in left lateral recumbency, with the head raised at a $30^{\circ}$ angle in relation to the table. The fiberoptic catheter was, then, surgically implanted (Mod.110-4BT, Integra Neurocare Camino Labs, San Diego, CA, USA (Proc. FAPESP 00/01084-3)) in the right superficial cerebral cortex, using an access kit (Mod. 5H-ITH-2, Integra Neurocare Camino Labs, San Diego, CA, USA (Proc. FAPESP 00/01084-3)), following the technique described by Bagley et al. (1995). The catheter was immediately connected to the intracranial pressure digital monitor (Mod. MPM-1, Integra Neurocare Camino Labs, San Diego, CA, USA (Proc. FAPESP 00/01084-3)) in order to measure intracranial pressure (ICP) and intracranial temperature (ICT). The cerebral perfusion pressure (CPP) was calculated by subtracting the ICP value from the MAP value.

After the implant, a catheter was placed surgically in the left femoral artery to monitor mean arterial pressure (MAP) using a multiparametric monitor (Dixtal mod. DX 2010, Invasive AP module, Manaus, AM, Brazil (Proc. FAPESP 02/04625-0)). A Swan-Ganz catheter was introduced surgically into the left femoral vein and advanced into the pulmonary artery to monitor cardiac output (CO). The confirmation of thermodilution catheter position was made by observation of the pressure curves. The $\mathrm{CO}$ was measured directly, through the thermodilution technique with a microprocessed device (Dixtal mod. DX 2010, CO module, Manaus, AM, Brazil (Proc. FAPESP 96/1151-5)).

The heart rate (HR) was obtained through a computerized electrocardiograph (TEB, mod. ECGPC software version 1.10, São Paulo, SP, Brazil (Proc. FAPESP 96/1151-5)) adjusted to lead II. While respiratory rate (RR) and end-tidal $\mathrm{CO}_{2}$ partial pressure $\left(\mathrm{PE}^{\prime} \mathrm{CO}_{2}\right)$ was obtained through an oxycapnograph (Mod.5250 RGM, Datex Ohmeda, Madison, WI, USA), which had a sensor adapted to the endotracheal tube. Core body temperature (BT) was monitored using an esophageal probe, advanced close to the base of the heart, and the multiparametric monitor (Dixtal mod. DX 2010, Manaus, AM, Brazil 
(Proc. FAPESP 96/1151-5)). Thirty minutes after implanting the fiber-optic catheter, $0.3 \mathrm{~mL} / \mathrm{kg}$ of cerebrospinal fluid (CSF) was collected from the cisterna magna using a sterile needle, and immediately the same volume of $30 \%$ iohexol (Omnipaque, Sanofi-Synthelabo Ltda., Rio de Janeiro, RJ, Brazil) was injected slowly over 90 seconds.

The variables were measured 30 minutes after the induction of anesthesia, immediately before CSF collection (TA), after CSF collection and iohexol administration (T0) and every 10 minutes after T0, for 60 minutes (T10 to T60).

Results were expressed as mean \pm SD. Kolmogorov-Smirnov normality test was applied to determine if the distribution was normal or not. In this way, the parameters of $\mathrm{PE}^{\prime} \mathrm{CO}_{2}, \mathrm{HR}$, $\mathrm{RR}, \mathrm{MAP}, \mathrm{ICP}, \mathrm{CPP}$ from both groups and $\mathrm{CO}$ and $\mathrm{BT}$ from $\mathrm{PG}$ were treated as non-parametric. ICT from both groups and $\mathrm{CO}$ and $\mathrm{BT}$ from SG were treated as parametric. Friedman test followed by Tukey's test was used for nonparametric data, and one way repeated measures analysis of variance followed by Student Newman-Keuls test for parametric data. These tests were used to analyze the changes in the parameters between different observation times (SigmaStat for Windows, version 3.0.1. Systat Software Inc., Richmond, CA, USA). Statistical significance was attributed when $\mathrm{P}<0.05$.

\section{RESULTS}

The ICP, in SG, decreased after iohexol administration (T0), and, at T60, the mean returned to baseline values. While means of CPP from T20 to T60 were lower than at T0 (Table $1)$. In the propofol group, no differences were observed for ICP, while the CPP increased after CSF collection and iohexol administration (T0). At T50 and T60, the CPP values were lower than the mean observed at T0.

Table 1. Means and standard deviations of intracranial pressure, cerebral perfusion pressure, intracranial temperature, mean arterial blood pressure, heart rate, cardiac output, respiratory rate, end-tidal carbon dioxide partial pressure and body temperature in dogs anesthetized with propofol or sevoflurane and submitted to subarachnoid administration of iohexol.

\begin{tabular}{|c|c|c|c|c|c|c|c|c|c|}
\hline \multirow{2}{*}{ Parameters } & & \multicolumn{8}{|c|}{ Times } \\
\hline & & TA & T0 & $\mathrm{T} 10$ & $\mathrm{~T} 20$ & $\mathrm{~T} 30$ & $\mathrm{~T} 40$ & T50 & T60 \\
\hline ICP & SG & $15 \pm 6$ & $10 \pm 3 \mathrm{~A}$ & $11 \pm 4$ & $11 \pm 5$ & $11 \pm 4$ & $12 \pm 4$ & $13 \pm 4$ & $14 \pm 5 B C$ \\
\hline$(\mathrm{mmHg})$ & PG & $17 \pm 8$ & $15 \pm 9$ & $14 \pm 10$ & $16 \pm 11$ & $16 \pm 11$ & $17 \pm 11$ & $17 \pm 11$ & $18 \pm 11$ \\
\hline CPP & SG & $71 \pm 14$ & $80 \pm 18$ & $69 \pm 18$ & $69 \pm 13 B$ & $67 \pm 12 B$ & $65 \pm 12 B$ & $65 \pm 12 B$ & $64 \pm 11 B$ \\
\hline$(\mathrm{mmHg})$ & PG & $82 \pm 18$ & $98 \pm 23 \mathrm{~A}$ & $96 \pm 21$ & $92 \pm 22$ & $92 \pm 20$ & $91 \pm 19$ & $89 \pm 17 B$ & $89 \pm 17 B$ \\
\hline ICT & SG & $37.7 \pm 1$ & $37.4 \pm 1$ & $37.2 \pm 1$ & $37.0 \pm 1 \mathrm{~A}$ & $36.8 \pm 1 \mathrm{AB}$ & $36.6 \pm 1 \mathrm{ABC}$ & $36.4 \pm 1 \mathrm{ABCD}$ & $36.3 \pm 1 \mathrm{ABCDE}$ \\
\hline$\left({ }^{\circ} \mathrm{C}\right)$ & PG & $37.6 \pm 1$ & $37.4 \pm 1$ & $37.3 \pm 1$ & $37.1 \pm 1 \mathrm{~A}$ & $37.0 \pm 1 \mathrm{AB}$ & $36.9 \pm 1 \mathrm{ABC}$ & $36.8 \pm 1 \mathrm{ABCD}$ & $36.6 \pm 1 \mathrm{ABCDE}$ \\
\hline MAP & SG & $86 \pm 12$ & $90 \pm 18$ & $79 \pm 19$ & $80 \pm 13 \mathrm{~B}$ & $78 \pm 12 B$ & $78 \pm 12 \mathrm{~B}$ & $78 \pm 13 B$ & $78 \pm 11 \mathrm{~B}$ \\
\hline$(\mathrm{mmHg})$ & PG & $99 \pm 17$ & $113 \pm 18 \mathrm{~A}$ & $110 \pm 17$ & $108 \pm 19$ & $108 \pm 17$ & $107 \pm 15$ & $106 \pm 13$ & $107 \pm 14$ \\
\hline HR & SG & $122 \pm 17$ & $117 \pm 21$ & $113 \pm 21$ & $115 \pm 19$ & $113 \pm 18$ & $113 \pm 17$ & $112 \pm 18$ & $113 \pm 18$ \\
\hline (beats minute $^{-1}$ ) & PG & $119 \pm 16$ & $122 \pm 14$ & $123 \pm 18$ & $119 \pm 17$ & $115 \pm 16$ & $118 \pm 20$ & $118 \pm 20$ & $116 \pm 20 B$ \\
\hline $\mathrm{CO}$ & SG & $2.3 \pm 1$ & $2.4 \pm 1$ & $2.5 \pm 0.7$ & $2.6 \pm 0.7$ & $2.6 \pm 0.7$ & $2.6 \pm 1$ & $2.6 \pm 1$ & $2.7 \pm 1 \mathrm{~A}$ \\
\hline$\left(\mathrm{L} \mathrm{minute}^{-1}\right)$ & PG & $2.6 \pm 1$ & $2.7 \pm 1$ & $2.5 \pm 1$ & $2.5 \pm 1$ & $2.5 \pm 1$ & $2.5 \pm 1$ & $2.5 \pm 1$ & $2.5 \pm 1$ \\
\hline RR & SG & $11 \pm 6$ & $9 \pm 6$ & $11 \pm 5$ & $12 \pm 7$ & $11 \pm 5$ & $11 \pm 5$ & $11 \pm 6$ & $11 \pm 7$ \\
\hline (breaths minute $^{-1}$ ) & PG & $6 \pm 4$ & $7 \pm 4$ & $8 \pm 6$ & $9 \pm 7$ & $9 \pm 9$ & $8 \pm 6$ & $7 \pm 6$ & $8 \pm 8$ \\
\hline $\mathrm{PE}^{\prime} \mathrm{CO}_{2}$ & SG & $43 \pm 5$ & $36 \pm 15$ & $48 \pm 11$ & $49 \pm 12 B$ & $47 \pm 13$ & $49 \pm 15$ & $44 \pm 18$ & $49 \pm 17$ \\
\hline$(\mathrm{mmHg})$ & PG & $58 \pm 11$ & $59 \pm 11$ & $57 \pm 11$ & $57 \pm 15$ & $59 \pm 16$ & $59 \pm 15$ & $58 \pm 16$ & $58 \pm 15$ \\
\hline BT & SG & $37.4 \pm 1$ & $37.2 \pm 1$ & $37.0 \pm 1$ & $36.8 \pm 1 \mathrm{~A}$ & $36.6 \pm 1 \mathrm{AB}$ & $36.4 \pm 1 \mathrm{ABC}$ & $36.3 \pm 1 \mathrm{ABCD}$ & $36.1 \pm 1 \mathrm{ABCDE}$ \\
\hline$\left({ }^{\circ} \mathrm{C}\right)$ & PG & $37.5 \pm 1$ & $37.4 \pm 1$ & $37.2 \pm 1$ & $37.1 \pm 16$ & $36.9 \pm 1 \mathrm{AB}$ & $36.8 \pm 1 \mathrm{ABC}$ & $36.7 \pm 1 \mathrm{ABCD}$ & $36.6 \pm 1 \mathrm{ABCD}$ \\
\hline
\end{tabular}

${ }^{\mathrm{A}}$ Different from TA; ${ }^{\mathrm{B}}$ Different from T0; ${ }^{\mathrm{C}}$ Different from T10; ${ }^{\mathrm{D}}$ Different from T20; ${ }^{\mathrm{E}}$ Different from T30 according to Student Newman Keuls test for parametric data and Tukey test for non-parametric data $(\mathrm{P}<0.05)$.

ICP: intracranial pressure, CPP: cerebral perfusion pressure, ICT: intracranial temperature, MAP: mean arterial blood pressure, HR: heart rate, $\mathrm{CO}$ : cardiac output, RR: respiratory rate, $\mathrm{PE}^{\prime} \mathrm{CO}_{2}$ : end-tidal carbon dioxide partial pressure, BT: body temperature. TA: measurement at 30 minutes after the induction of anesthesia and immediately before CSF collection; T0: after CSF collection and iohexol administration; T10: 10 minutes after T0; T20: 20 minutes after T0; T30: 30 minutes after T0; T40: 40 minutes after T0; T50: 50 minutes after T0; T60: 60 minutes after T0. 
Intracranial temperature decreased in both groups gradually. From T20 to T60, ICT was lower than at TA. From T30 to T60 ICT was lower than at T0; from T40 to T60, ICT was lower than at T10, from T50 and T60 was lower than at T20, and at T60 it was lower than at T30. The body temperature showed similar changes to ICT.

The MAP in SG was lower from T20 to T60 than at T0. In PG, MAP at T0 was higher than at TA. The HR did not differ significantly among times in SG. In PG, HR was lower at T60 when compared with T0. Cardiac output in the PG remained constant while in $\mathrm{SG}$, at $\mathrm{T} 60$, the value of $\mathrm{CO}$ was higher than at TA. The $\mathrm{RR}$ and $\mathrm{PE}^{\prime} \mathrm{CO}_{2}$ in $\mathrm{PG}$ remained constant. In the $\mathrm{SG}$ the RR did not differ significantly over time, but $\mathrm{PE}^{\prime} \mathrm{CO}_{2}$ was higher at T20 than at T0.

\section{DISCUSSION}

Autoregulation of brain blood flow is usually very effective in a systemic mean arterial blood pressure range of approximately 60 to $140 \mathrm{mmHg}$. Within this range of blood pressure, many factors (e.g.: hypercpania, severe hypoxia, many anesthetics) interfere with autoregulation and cause change in ICP (Harvey et al., 2007). The threshold $\mathrm{PaCO}_{2}$ to significantly impair cerebral autoregulation ranged from 50 to 66 $\mathrm{mmHg}$ during propofol or sevoflurane anesthesia in humans (McCulloch et al., 2000). Hypercapnia states correlate with increases in ICP and a rise in cerebral blood volume (Smith et al., 1970).

Considering that in both groups, MAP means were within the range of 60 to $140 \mathrm{mmHg}$ (Table 1 ), the evaluation of the arterial partial pressure of carbon dioxide $\left(\mathrm{PaCO}_{2}\right)$ should be very important, because $\mathrm{PaCO}_{2}$ is the most potent regulator of cerebral autoregulation (Westbrook and Cunningham, 2001).

Thus, in this study $\mathrm{PE}^{\prime} \mathrm{CO}_{2}$ was recorded, because these values can be used as a noninvasive measure of arterial $\mathrm{CO}_{2}$ and in the absence of significant pulmonary disease or reduction in cardiac output, the difference between $\mathrm{PaCO}_{2}$ and $\mathrm{PE}^{\prime} \mathrm{CO}_{2}$ will be less than 5 $\mathrm{mmHg}$ (Armitage-Chan et al., 2007). In this study, the dogs were healthy and $\mathrm{CO}$ did not decrease during the whole study in both groups.
In the sevoflurane group, from T10 hypercapnia was observed, with means of $\mathrm{PE}^{\prime} \mathrm{CO}_{2}$ higher than $45 \mathrm{mmHg}$ (Muir III and Hubell, 1997), but lower than $50 \mathrm{mmHg}$. According to McCulloch et al. (2000), $\mathrm{PaCO}_{2}$ ranging from 50 to $66 \mathrm{mmHg}$ can impair cerebral auto-regulation. It is important to describe that in $\mathrm{SG}$, some dogs had $\mathrm{PE}^{\prime} \mathrm{CO}_{2}$ higher than $50 \mathrm{mmHg}$ that could impair autoregulation. However, analysis of $\mathrm{PE}^{\prime} \mathrm{CO}_{2}$ means suggested that cerebral autoregulation was preserved. This hypothesis can be confirmed by ICP and CPP stability observed after CSF collection and iohexol administration. In spite of $\mathrm{PE}^{\prime} \mathrm{CO}_{2}$ increasing from T10, ICP and CPP values did not differ of means registered when normocapnia was present.

In $\mathrm{PG}$, during the whole procedure, the $\mathrm{PE}^{\prime} \mathrm{CO}_{2}$ values were maintained within 50 to $66 \mathrm{mmHg}$ (McCulloch et al., 2000), indicating a hypercapnia state. Thus, it was not possible to identify the propofol effect on intracranial parameters, because carbon dioxide influenced cerebral autoregulation. Hypercapnia was present before CSF collection (TA). Thus, this event can be attributed to propofol, because this drug reduces contractility of the canine diaphragm in a dose-related fashion (Fujii et al., 2004) and can also decrease the arterial partial pressure of oxygen $\left(\mathrm{PaO}_{2}\right)$ and increase the $\mathrm{PaCO}_{2}$ (Fantoni et al., 1999).

Normal ICP in dogs and cats is between 7 and 12 mmHg (Bagley et al., 1995; Dewey et al., 1997). According to Plochl et al. (1999), ICP values up to $15 \mathrm{mmHg}$ are normal for dogs. In $\mathrm{SG}$, the ICP means were within the normal values during the whole experiment. Rezende (2004), in dogs anesthetized with sevoflurane and maintained at normocapnia $\left(\mathrm{PE}^{\prime} \mathrm{CO}_{2}=35 \mathrm{mmHg}\right)$ by pressure controlled ventilation, observed a mean ICP of $17 \pm 4 \mathrm{mmHg}$. These values were slightly higher than ICP means at T0. This difference is probably due to mechanical ventilation used by Rezende (2004), because the application of positive pressure ventilations may increase ICP by decreasing venous return from the head (Armitage-Chan et al., 2007). Besides, at T0, ICP decreased possibly due to interference in the cerebral autoregulation caused by the alteration in transmural pressure related to the withdrawal of CSF and iohexol administration (Bagley et al., 1995). 
Although the most volatile anesthetics have dose-related effects on ICP (Armitage-Chan et al., 2007), in this study, sevoflurane did not change ICP because this drug does not impair pressure auto-regulation until concentrations exceed 1.5 MAC (3.3\%) with normal $\mathrm{PaCO}_{2}$ (McCulloch et al., 2000). The anesthetic protocols were adjusted to maintain the animals in stage III, plane $2 / 3$ according to Guedel planes, and the 1.5 MAC of sevoflurane was sufficient for it. Besides, at TA, T0 and T50, the $\mathrm{PE}^{\prime} \mathrm{CO}_{2}$ means were within the normal range for the species. Thus, it was suggested that this anesthetic did not change the autoregulation and, consequently, the ICP.

In propofol group, at TA, ICP did not remain within the normal range for the species (Bagley et al., 1995; Dewey et al., 1997; Plochl et al., 1998). That can be explained by the high $\mathrm{PE}^{\prime} \mathrm{CO}_{2}$ values recorded in this group. Hypercapnia increases ICP and correlates with a rise in cerebral blood volume (Smith et al., 1970).

In PG, at T0, after iohexol was administered, no difference was observed in ICP, but it was expected that the ICP could decrease due to the alteration in transmural pressure related to the withdrawal of CSF and iohexol administration (Bagley et al., 1995). In this group, no changes in ICP means were observed after iohexol injection, suggesting that this happened due to hypercapnia (Smith et al., 1970).

The normal interval for CPP is between 50 and $150 \mathrm{mmHg}$ (Steiner and Andrews, 2006). Hence, values recorded in this study were within physiological intervals, maintaining an adequate cerebral blood flow during the anesthetic. In SG, from T20 on, the CPP means were lower than the value registered at $\mathrm{T} 0$. This was attributed to a decreased MAP (from T20 on), which influences CPP three to four times more than ICP (Sponheim et al., 2003). In PG, an increase of $\mathrm{CPP}$, at T0, was attributed to MAP increase recorded at the same time. From T50 on, CPP values were lower than the mean at T0. This event probably occurred due to the hypercapnia state that induces cerebral vasodilation (Ito et al., 2003).

Sevoflurane usually causes a dose-dependent decrease in arterial blood pressure (Branson et al., 2001). Although, Rezende (2004) observed stability for MAP in dogs anesthetized with 1.5 MAC of sevoflurane, differing from this study that administered the same dose, but recorded, from T20 on, MAP values lower than at T0. The nociceptive stimulation associated with the administration of the contrast caused MAP increase at T0, but without statistical significance, which could be explained by the Monroe-Kellie doctrine and the relationship between CPP, MAP and ICP. Thus, the difference between this and Rezende's study could be explained because the last author did not perform CSF collection and iohexol administration in her animals.

Propofol decreases arterial blood pressure (Short and Bufalari, 1999). However, in this study, MAP increased at T0. Again, a nociceptive stimulation associated with the administration of the contrast could have promoted the mean arterial pressure increase at T0. After this moment, the MAP means were stable, not differing from T0. This observation corroborated Nunes et al. (2008) who did not record changes in MAP in dogs submitted to continuous infusion of propofol $(0.7 \mathrm{mg} / \mathrm{kg} / \mathrm{minute})$, breathing spontaneously with several inspired oxygen fractions.

The HR and CO were stable during the whole experiment in SG corroborating Rezende (2004), who did not observe changes in these parameters in sevoflurane-anesthetized dogs. In PG, the stability of $\mathrm{HR}$ and $\mathrm{CO}$ corroborates data registered by Nunes et al. (2008). According to Ferro et al. (2005), in dogs breathing spontaneously, the continuous rate infusion of propofol $\left(0.2 ; 0.4\right.$ and $0.8 \mathrm{mg} \mathrm{kg}^{-1}$ minute $\left.^{-1}\right)$ did not promote changes in heart rate.

In both groups, ICT decreased body temperature, which was due to several factors such as: room temperature, fluid administration, reduction of metabolism and peripheral vasodilatation caused by the anesthetic agents (Cortopassi, 2002).

Respiratory depression and apnea can occur during iohexol injection when it is administered too fast (Adams, 1982) or as a result of a lesion at the bulbo-medular junction during the placement of the needle for cervical myelography (Simon and Nicholas, 1999). Important alterations in RR were not observed in 
any group, showing that sevoflurane and propofol maintained spontaneous ventilation and seemed to be adequate regarding this variable during the myelogram.

In conclusion, the cerebrospinal fluid collection and administration of non-ionic contrast promoted decrease in intracranial pressure in sevoflurane-anesthetized dogs and increase in cerebral perfusion pressure in propofolanesthetized dogs. Additionally, in dogs, cerebral autoregulation was impaired by hypercapnia during continuous rate infusion of propofol $(0.55 \pm 0.15 \mathrm{mg} / \mathrm{kg} / \mathrm{minute})$ and preserved during sevoflurane anesthesia (1.5 CAM). However, anesthesia with propofol or sevoflurane, at the used doses, does not cause alterations that could jeopardize the myelography.

\section{ACKNOWLEDGEMENTS}

The authors would like to thank the Fundação de Amparo à Pesquisa do Estado de São Paulo FAPESP, for the financial support and scholarship.

\section{REFERENCES}

ADAMS, W.M. Myelography. Vet. Clin. N. Am.: Small. Anim. Pract., v.12, p.295-311, 1982.

ARMITAGE-CHAN, E.A.; WETMORE, L.A.; CHAN, D.L. Anesthetic management of the head trauma patient. J. Vet. Emerg. Crit. Care, v.17, p.5-14, 2007.

BAGLEY, R.S.; KEEGAN, R.D.; GREENE, S.A. et al. Pathologic effects in brain after intracranial pressure monitoring in clinically normal dogs, using a fiberoptic monitoring system. Am. J. Vet. Res., v.56, p.1475-1478, 1995.

BAZIN, J.E. Effects of anesthetic agents on intracranial pressure. Anesth. Rean., v.16, p.445-452, 1997.

BRANSON, K.R.; QUANDT, J.E.; MARTINEZ, E.A. et al. A multisite case report on the clinical use of sevoflurane in dogs. J. Am. Anim. Hosp. Assoc., v.37, p.420-432, 2001.

CHARLES, E.S.; FALLON, W.F. Sevoflurane mask anesthesia for urgent tracheostomy in an uncooperative trauma patient with a difficult airway. Can. J. Anaesth., v.47, p.242-245, 2000.

CLARKE, K.W. Desflurane and sevoflurane: new volatile anesthetic agents. Vet. Clin. N. Am. Small Anim. Pract., v.29, p.793-810, 1999.
CORTOPASSI, S.R.G. Anestesia pediátrica. In: FANTONI, D.T.; CORTOPASSI, S.R.G. (Eds.). Anestesia em cães e gatos. 1.ed. São Paulo: Rocca, 2002. p.216-221.

CRYSTAL, G.J.; ZHOU, X.; GUREVICIUS, J. et al. Direct coronary vasomotor effects of sevoflurane and desflurane in situ canine hearts. Anesthesiology, v.92, p.1103-1113, 2000 .

DENEUCHE, A.; DESBOIS, C. Propofol 2 Indications and Contra-indications. Point. Vet., v.30, p.35-40, 1999.

DEWEY, C.W.; BAILEY, C.S.; HASKINS, S.C. et al. Evaluation of an epidural intracranial pressure monitoring system in cats. J. Vet. Emerg. Crit. Care, v.6, p.20-33, 1997.

FANTONI, D.T.; CORTOPASSI, S.R.G.; BERNARDI, M.M. Anestésicos intravenosos e outros parenterais. In: SPINOSA, H.S.; GÓRNIAK, S.L.; BERNARDI, M.M. (Eds.). Farmacologia aplicada à medicina veterinária. Rio de Janeiro: Guanabara Koogan; 1999. p.114-124.

FERRO, P.C.; NUNES, N.; PAULA, D.P. et al. Variáveis fisiológicas em cães submetidos à infusão contínuade diferentes doses de propofol. Cienc Rural, v.35, p.1103-108, 2005.

FUJII, Y.; UEMURA, A.; TOYOOKA, H. The recovery profile of reduced diaphragmatic contractility induced by propofol in dogs. Anesth. Analg., v.99, p.113-116, 2004.

GLOWASKI, M.M.; WETMORE, L.A. Propofol: application in veterinary sedation and anesthesia. Clin. Tech. Small Anim. Pract., v.14, p.1-9, 1999.

HANOUZ, J.L.; MASSETTI, M.; GUESNE, G. et al. In vitro effects of desflurane, sevoflurane, isoflurane and halothane in isolated human right atria. Anesthesiology, v.92, p.116, 2000.

HARVEY, R.C.; GREENE, S.A.; THOMAS, W. Neurological disease. In: TRANQUILLI, W.J.; THURMON, J.C.; GRIMM, K.A. (Eds). Lumb \& Jones' Veterinary anesthesia and analgesia. 4nd ed. Oxford: Blackwell, 2007. p.903-913.

ITO, H.; KANNO, I.; IBARAKI, M. et al. Changes in human cerebral blood flow and cerebral blood volume during hypercapnia and hypocapnia measured by positron emission tomography. J. Cereb. Blood Flow Metab., v.23, p.665-670, 2003.

LEITE, A.V.; NUNES, N.; REZENDE, M.L. Anestesia para mielografia em cães. Cienc. Rural, v.32, p.725-729, 2002. 
LEWIS, D.D.; HOSGOOD, G. Complications associated with the use of iohexol for myelography of the cervical vertebral column in dogs: 66 cases (19881990). J. Am. Vet. Med. Assoc., v.200, p.1381-1384, 1992.

MAGELLA, H.A.; CHEIBUB, Z.B. Propofol: Revisão bibliográfica. Rev. Bras. Anest., v.40, p.289-294, 1990

McCULLOCH, T.J.; VISCO, E.; LAM, A.M. Graded hypercapnia and cerebral autoregulation during sevoflurane or propofol anesthesia. Anesthesiology, v.93, p.1205-1209, 2000.

MONKHOFF, M.; SCHWARZ, U.; GERBER, A. et $a l$. The effects of sevoflurane and halothane anesthesia on cerebral blood flow velocity in children. Anesth. Analg., v.92, p.891-896, 2001.

MUIR III, W.W.; HUBBELL, J.A.E. Manual de anestesia veterinária. 2 ed. Madrid: Mosby, 1997. $503 p$.

NUNES, N.; LOPES, P.C.F.; SANTOS, P.S.P. et al. Hemodinâmica de diferentes frações inspiradas de oxigênio em cães submetidos à infusão contínua de propofol sob ventilação espontânea Cien Rural, v.38, p.729-735, 2008 .

OMOIGUI, S. Manual de Drogas Usadas em Anestesia. 2ed. São Paulo: Livraria Santos Editora, 1998. 566p.

PAULA, D.P.; NUNES, N.; NISHIMORI, C.T.D. et al. Efeitos da infusão contínua de propofol ou etomidato sobre variáveis intracranianas em cães. Arq. Bras. Med. Vet. Zootec., v.62, p.302-308, 2010.

PLOCHL, W.; COOK, D.J.; ORSZULAK, T.A. et al. Critical cerebral perfusion pressure during tepid heart surgery in dogs. Ann. Thorac. Surg., v.66, p.118-124, 1999.

QUANDT, J.E.; ROBINSON, E.P.; RIVERS, W.J. et al. Cardorespiratory and anesthetic of propofol and thiopental in dogs. Am. J. Vet. Res., v.59, p.11371143,1998

RAVUSSIN, P.; GUINARD, J.P.; RALLEY, F. et al. Effect of propofol on cerebrospinal fluid pressure and cerebral perfusion pressure in patients undergoing craniotomy. Anaesthesia, v.43, p.37-41, 1988.
REZENDE, M.L. Efeitos do sevofuorano $e$ do desfluorano sobre variáveis intracranianas $e$ hemodinâmicas em cães. 2004. 102f. Tese (Doutorado em Cirurgia Veterinária) - Faculdade de Ciências Agrárias e Veterinárias, Universidade Estadual Paulista, Jaboticabal, SP.

SCHWENDER, D.; TERMINE, H.; DAUNDERER, M. et al. Sevoflurane and the nervous system. Anaesthesist, v.47, p.S37-S42, 1998.

SHORT, C.E.; BUFALARI, A. Propofol anesthesia. Vet. Clin. N. Am.: Small Anim. Pract., v.29, p. 747778, 1999.

SIMON, J.W.; NICHOLAS, J.H.S. Diagnóstico e tratamento cirúrgico das afecções espinais do cão e do gato. 1.ed. São Paulo: Manole, 1999. p. 46-48.

SMITH, A.L.; NEUFELD, G.R.; OMINSKY, A.J. et al. Interrelations among cerebral blood flow, mean transit time, and vascular volume. Fed. Proc., v.29, p.519, 1970 .

SPONHEIM, S.; SKRAASTAD, O.; HELSETH, E. $e t$ al. Effects of 0.5 and 1.0 MAC isoflurane, sevoflurane and desflurane on intracranial and cerebral perfusion pressures in children. Acta Anaesthesiol. Scand., v.47, p.932-938, 2003.

STEINER, L.A.; ANDREWS, J.D. Monitoring the injured brain: ICP and CBF. Brit. J. Anaesth., v.97, p.26-38, 2006.

WESTBROOK, A.; CUNNINGHAM, A.J. Comment In: McCULLOCH, T.J.; VISCO, E.; LAM, A.M. Graded hypercapnia and cerebral autoregulation during sevoflurane or propofol anesthesia. Survey Anesthesiol., v.45, p.343-344, 2001.

WHITWAM, J.G.; GALLETLY, D.C.; MA, D. et al. The effects of propofol on heart rate, arterial pressure and $\mathrm{A}$ and $\mathrm{C}$ somatosympathetic reflexes in anesthetized dogs. Eur. J. Anaesth., v.17, p.57-63, 2000.

WIDMER, W.R.; BLEVINS, W.E.; JAKOVLJEVIC, S. et al. Iohexol and iopamidol myelography in the dog: a clinical trial comparing adverse effects and myelographic quality. Vet. Radiol. Ultrasound, v.33, p.327-333, 1992. 